\title{
The strategies of small class teaching for college English teachers
}

\author{
Xiaohui Wang \\ Foreign Language School, North-East Dianli University, JiLin, China \\ wxhxuna@126.com
}

\begin{abstract}
Due to the different emphasis westerners and Chinese understand "small class English teaching "differently. Westerners pay more attention to the number of students when "small class English teaching is mentioned"; while Chinese advocate the spirit of "small class English teaching". Chinese purpose is to promote students' development in all-around way. This essay focuses on both of the two ideas. Obviously, small class teaching can benefit both the students and the teachers. But it is a big challenge for college teachers to change their teaching methods, teaching principals, teaching skills and techniques because they are accustomed to the old way. Setting up clear teaching and learning goals, encouraging students' participation, reflecting teaching process constantly, building up effective assessment system for students' class performance and cultivating their team spirit are the key factors to "small class English teaching".
\end{abstract}

Keywords-Strategy; small class; technique; quality

\section{INTRODUCTION}

Small class English teaching is prevalent in western countries while it is unusual in China. Due to the Chinese massive population it is hard for Chinese college English teachers to have a small class for English teaching. As visiting scholars of Salem State University, Zhouliang Xie, Li Ma, Yanfen Mao, Kang Shi and I have been attending and observing the small class ESL(English as a second language)teaching for half a year. Based on our survey and interview of the ESL students and teachers, the advantages and limitations of small class teaching are revealed. The effectiveness of small class English teaching is highly affected by teaching skills of the instructors as well as the learners' interests. Although students are the focus of the class, teachers play a critical role for the effectiveness of students' learning in a small class.

\section{CHARACTERISTICS AND FUNCTIONS OF SMALL CLASS ENGLISH TEACHING}

\section{A. Definition of small class English teaching}

What is a small class English teaching? Different scholars have various ideas for this concept. According to a scholar from Hong Kong, Americans believe that it is a small class teaching when the number of the students in a classroom is less than 20; while British holds the opposite idea that the number of the students should be less than 25.[1] In mainland of China most scholars argue that the number of the students in a small class should be between 25-32 and Scholars in Hong Kong insist that the number would be within 23-25. Based on the above ideas we may define small class English teaching as an English teaching in a small class where the number of the students is between 25 and 30 . This definition focuses on the number of students in a class. Many Americans probably will agree with that idea because small class teaching in America just implies that there are minor students in the classroom. But in China " small class teaching "not only refers to the small scale students but also emphasizes the new teaching method and innovative principle comparing with the traditional big class teaching, whose key is to improve the relationship between teachers and students in order to get the harmony of teaching and learning.

\section{B. Peculiar features of small class English teaching}

Based on the above research the characteristics and functions of small class English teaching can be described as the following facts. In small class English teaching the number of the students is between 20 and 30 ; teachers are the guiders; students are the center of the class; during the teaching process teachers control the activities and observe the reactions of students; teachers may change teaching methods and teaching process corresponding to the students' responses. In short, small class English teaching is dynamic and teachers as well as students make a progress through discussion and cooperation in a friendly way. Because of small class teaching environment, students will get more teachers' individual attention, which is beneficial to the positive interaction between the teachers and students, to the development of students' emotions, attitudes and values. [3]

\section{QUALITIES OF TEACHERS FOR SMALL CLASS ENGLISH TEACHING}

Due to the transformation from the big class English teaching to small class English teaching, college English teachers should build up new principals of teaching English, improve their English level, and enhance their teaching and research abilities.

In the first place, college English teachers not only should master English skills of listening, speaking, reading, writing and translating but they also should grasp the knowledge of language, English culture, common senses related to 
educational objects, the characteristics of college English course, the methods and theories of foreign language education and psychological knowledge. In the second place, it is necessary for college English teachers to build up modern foreign language teaching principles. In other words, teachers shouldn't focus on teaching but concentrate on students' ability of self-study. It is critical to develop students' comprehensive abilities. In addition, college English teachers should apply the principles of people first to the process of developing students. For college English teachers they should pay more attention to students' language and communicative competence during the process of developing students in all-around way. In the third place, college English teachers should grasp the following teaching and research abilities. First, teaching design is very important, so college English teachers should master the creative abilities to design teaching, which can integrate the various factors of teaching process so as to realize teaching purpose. Second, college English teachers should develop a way to effective teaching, which can facilitate all the internal and external factors to guarantee the execution of curriculum plan, teaching plan and teaching strategies. Third, college Teachers should have the abilities to scrutinize teaching process effectively, which can monitor teaching process and the process of students' self study. Forth, college teachers should reflect teaching frequently. Research staffs from Hong Kong noticed that if teachers are planning to impact their students on their learning substantially through small-class teaching, they must constantly reflect their teaching and promote the professional career through the means of cooperation inquiry. Besides, they should build up professional learning community, and ultimately realize the teachers' professional development, spiral reciprocity between students' learning improvement and teachers' teaching practice and reflection. [4] College English teachers should constantly improve their self-awareness, evaluate their teaching objects, teaching principals, assess teaching process and adjust their teaching behaviors. Fifth, college English teachers should be good at teaching assessment which requires them to collect the teaching materials, to choose and use the proper assessment methods as well as tools, to analyze or explain the assessment materials and results accurately. Sixth, college teachers should have the abilities to carry out scientific experiments including individual and collective experimenting abilities. Seventh, college teachers should know how to collect scientific statistics and how to carry out mathematical statistics analysis. Eighth, college English teachers should be versed in qualitative and quantitative analysis. Last but not least, college English teachers should enhance their teaching and research abilities especially when modern educational techniques are employed.

\section{SPECIFIC TECHNIQUES OF COLLEGE ENGLISH TEACHERS FOR SMALL CLASS TEACHING}

In order to teach small class more effectively Board of Education in Hong Kong reaches the following conclusions by carrying out some specific experiments. Above all, learning goals should be thoroughly clear so that students know what they must learn and what is optional. In addition, teachers should use extended questioning techniques in small class teaching. Extend questions can form a question group, which can make students think a question over and over. Next, students' active participation is vital in group discussion or team work. So, teachers should encourage students to express themselves or coordinate with each other. After that, teachers should send some feedbacks to students regularly with the purpose that students can reflect themselves. Finally, teachers should assess students' performances positively, which can reinforce students' learning motivation. [5]

\section{A. How to know the students}

The typical features of small class teaching are to develop students individually. In another words, individual teaching places a lot of emphasis on the best development of anyone in the small class. If a college English teacher is planning to develop every student's English well, he/she must know the students very well. In this case college English teachers must prepare teaching materials well in advance in order to suit the best interest of every student. So it is necessary for the college teachers to look through the students files or to talk to some specific students. Maybe sometimes teachers should interview or set up some placement tests so that they can know students exactly. It is critical for college English teachers to know their students well because it is the key to success in small class English teaching.

\section{B. How to filter teaching content}

The big difference between small class English teaching and the big one lies in the skills of filtering content. Usually in a big class English teaching a textbook will be used for all the students to study and the college English teachers will teach what the textbook offers. So, the needs of all the individuals can't be satisfied. As a result, some unnecessary contents have been being learned while most students have already mastered the knowledge. But in the small class English teaching college English teachers have more freedom to choose the necessary teaching materials. Due to different comprehensive qualities of College English teachers some college teachers can provide students with better materials while others may do a bad job. It is a big challenge for many college English teachers to choose appropriate materials. The technique is that the materials that college English teachers choose should not only arouse students' interests but it also is professional and has a little higher level than students have already acquired.

\section{Teaching method of small English class}

Another technique is related to teaching method. As is well known that lecture is preferred in big class English teaching because it can convey more knowledge in a short time. If college English teachers allow students to express their opinions one by one, the teaching content can't be finished as it is expected. While in small class English teaching, discussion and debating can be used during the teaching process so that individuals will not only practise their listening and speaking but also express their ideas which are very essential to educated adults in any society. When college English teachers employ the discussion and debating methods, the following tips are important for them to pay attention to. First, the class which is dominated by one or several students should be avoided. Second, college teachers should not only 
listen to the speakers and make a response approriately and but they also should notice the behaviors of the listeners in detail so as to make the teaching process go smooth and effective.

\section{Words of teachers for small English class}

When and where college teachers should interrupt or stop the speakers is up to the teachers' judgment. The language which is used in the small class teaching plays an important part in the effectiveness of the class. Usually we say teachers make a lecture in a big class which is prepared before the class, so it's easy for college English teachers if they recite or memory the words of the lecture. But it's very hard for college English teachers to choose proper words to comment on students' statements or students' class performances. In general, the words that teacher use to comment should not flatter the students and also should not scold them. It is an art that teachers' words can encourage students to correct their errors themselves and It is good to make neutral comments if students try their best to learn.

\section{E. Assessment mode of small English class}

Most college English teachers tend to evaluate students' achievement by mid-term exam plus final exam because it is convenient for teachers to do so with large number of students. Yet in order to develop students properly the evaluation process of students should be divided into several parts and the tools should be various including subjective and objective means.

\section{SUMMARY}

Although small class teaching is not new, it is new in China comparing to the current big class college English teaching. With the reform of teaching methods and principals the emphasis of college English teaching should be shifted from teachers to students. Students play main roles in the new teaching concept, but teachers' techniques are the key to teaching successfully. Qualified college English teachers not only should master better English skills but also they should know common knowledge of pedagogy and psychology. Besides, college English teachers should be easygoing and open-minded so that more students are willing to learn from them. In order to achieve ideal teaching effects teachers must try to improve their qualities and reflect their teaching constantly. Moreover, the ability to balance group discussion, the skills of commenting on students' responses in class and the competence to control the class are all keys to fulfilling the teaching objects.

\section{ACKNOWLEDGMENT}

Thank Sarah Detrich (an assistant professor of Salem State University of America) for her guidance and help.

\section{REFERENCES}

[1] Jianyuan Ye, "On the history of small class teaching and its experiences in Hong Kong,"Management of Elementary and Middle Schools, vol. 9, pp. 004-006, September 2010.

[2] Xi Sun, A comparison between Chinese and American small class teaching reform , Journal of Jiangsu Institute of Education., vol. 6. pp.27-30, June 2007 .

[3] BLATCHFORD P,BASSETT P,BROWN P, "Examining the effect of class size on classroom engagement and teacher -pupil interaction: Differences in relation to pupil prior attainment and primary vs. secondary schools," .Learning and Instruction, vol. 21, pp. 715-730, June 2011.

[4] HARFITT G J, “An examination of teachers' perceptions and practice when teaching large and reduced-size classes: Do teachers really teach them in the same way," Teaching and Teacher Education, vol. 28, pp. 132-140, January 2012.

[5] Hong Kong board of education. Small class teaching [ EB/OL ] ( 2010-05-07 ) [ 2013-04-16 ] .http://www.legco.gov.hk/yr0910/chinese/pan - els/ed/papers/ed0513cb2-1484-7-c.pdf. 